\title{
Author's right
}

\section{Editorial}

As an author, I understand your frustration. You have to answer questions from eminent or amateur reviewers and editors politely and carefully no matter the questions are relevant or not; you have to do more experiments no matter the request is reasonable or not; you have to change your wordings even you have contemplated them for a long time; you have to change your title to suit the journal's taste; you have to change the name of your newly developed method; you have to make the manuscript the right length; you have to make it the right style; you have to make the references the right format for the journal; you have to adjust each time you submit to a different journal; you have to wait for the final verdict for months; you have to worry if your competitor can publish earlier; you have to be judged by the citation numbers of other papers published on the same journal; you have to sign to give up the right. It is hard to publish if you have only an idea; it is hard if you only want to publish your opinion; it is hard if your experiment is not nearly perfect; it is hard if your result is negative; it is hard if your English is not native.

The saddest thing is you are scooped sometime, not because your scientific idea was wrong, not because you finished your experiments late, but only because you first submitted to a place which was not suitable for your work, you happen to have one of your competitor as reviewer, you happen to be in a country where misconducts are more often, or you happen to send in at editor's vacation time. Some people may even miss the chance of renewing grant, or even being awarded. Internet changes everything. It changes the way you find information; it changes the way you communicate; it changes the way you order your lab supply; it changes the way you find a job or job seeker; it changes the way you attend a meeting; it changes the way you give a seminar; it changes the way to start up a journal; it changes the way you submit to a journal; it changes the way the reviewer read your manuscript; it changes the way you pay for the open access. Most importantly it changes the way common people publish their own voice. But as a scientist, you are not that lucky. You don't have the right to publish the way you want to. The journal, the editor, the reviewers are in command. If you do not publish in the way the biology community conserved for so many years, you are not evaluated and valued normally. You were looked down if you do not publish your result in so called main stream journals.

We said we encourage creativity, we said we want you to be the first. Theoretically the scientist should be responsible for creating the novelty. If the scientist is the first to create, to discover, theoretically we should not let others, not even the second or the third who followed the first, who realized the importance of the work later than the first, to do the judgment. We should let the scientist publish the work before being judged. That is the respect the scientist who is the first deserves. New things are in definition in its early stage, they are hard to be perfect. We should not measure the perfection of the evidences at early stage. We should allow them to be perfected gradually. For encouraging creativity, giving new things a high standard may not be as good as allowing them to be published at early stage and then improve. It is the early stage of discovery that the scientist needs the protection the most. The best protection of a new idea is not to insulate the whole lab, is not to prohibit talking to friend and family. Discussion
Volume 2 Issue 5 - 2015

\author{
Youhe Gao \\ Department of Biochemistry and Molecular Biology, Beijing \\ Normal University, China
}

Correspondence: Youhe Gao, Department of Biochemistry and Molecular Biology, Beijing Normal University, Gene Engineering and Biotechnology Beijing Key Laboratory, Beijing, I00875, P. R. of China, Tel 86I058804382, Email gaoyouhe@bnu.edu.cn

Received: November II, 2015 | Published: November 16, 2015

makes the progress even faster. The best protection to the new idea is to publish it as soon as possible, even when it is not perfect. ${ }^{1}$ Readers will realize by themselves if the evidence is strong enough or not. Readers can see how big the sample size is. At the internet age, the novel is shorter, the letter is shorter, the instant message becomes shorter. Why do we have to keep the scientific research paper lengthy and perfect? If TED talk can be done in 18 minutes, the research paper should be allow to publish with only one experiment at a time. For a new system truly for author, there are only three things the journal should do. The first is to verify the submission is done really by the author his/herself, with his/her official working email address, with the name in the native language form, with ORCID like scientist ID, with personally ID number or even with photocopy of driver's license. The second is that the journal should also be responsible for giving the precise time stamp (not day stamp) like an official notary service. The third is to keep the permanent record of the paper searchable. The newer version can be added, but the old one is not retractable. They can only be earmarked. Author has to take his/her submission very seriously. Author should have the right to decide everything including the form, the length, the style, the wording, the terms, the online time, the link to data deposit, the video format, the supplement, the conflict of interest, the ethical approval and the copy right. Single experiment, posters, data tables, speculations, raw data and protocols should all be welcome. The author should pay for the maintenance cost to keep the journal (or an archive site) financially sustainable. The most important of all, the author has the right and obligation to keep his/her own name respectable because it is not retractable.

People may say it is an archive or a blog, it is informal, it is unofficial. As long as the system protects the creativity, it will be accepted by the community sooner or later. A scientist will be evaluated by the contents of his/her scientific blog, not the impact of that website. Let's skip the archive, the preprint; it only delays the painstaking reviewing process. No matter how fast the reviewing process goes, you can't beat the NPR (No Peer Review). Let's just publish it the way you want to. Eventually, author's right. At least in my dream. ${ }^{2}$

\section{Acknowledgements}

This work was supported by the National Basic Research Program 
of China (2012CB517606, 2013CB530805), the Key Basic Research Program of China (No. 2013FY114100).

\section{Conflict of interest}

The author declares no conflict of interest.

\section{References}

1. h t t p : / / b log. s c i e n c e n e t. c n / ho m e . php? $\bmod =$ space $\&$ uid $=244733 \&$ do $=$ blog $\&$ id $=933776$

2. http://blog.sciencenet.cn/blog-244733-746971.html 